\title{
A LITERATURE REVIEW OF NOVEL COVID-19 AND RELATED CORONAVIRUSES OUTBREAKS IN THE 1960S UNTIL 21ST CENTURY
}

\author{
Nurhafizul Abu Seri ${ }^{1}$ \\ ${ }^{1}$ GeoInformatic Unit, \\ Geography Section, School of Humanities, \\ Universiti Sains Malaysia, 11800 USM, \\ Pulau Pinang, \\ Malaysia.
}

*Corresponding author: Anisah Jessica Lee

\author{
Anisah Jessica Lee 2* $^{\text {* }}$ \\ ${ }^{2}$ Assosiate Professor, \\ GeoInformatic Unit, Geography Section, \\ School of Humanities, \\ Universiti Sains Malaysia, \\ 11800 USM, Pulau Pinang, \\ Malaysia.
}

Article DOI: https://doi.org/10.36713/epra5795

\begin{abstract}
Coronavirus (CoVs) is a large group of viruses known to affect birds and mammals including humans. This review aims to present the types of human coronavirus and animal coronavirus studied and displaying the relationships of these coronaviruses to weather, meteorology and climatology. Human coronaviruses (HCoV) in review are namely 229E, NL63, OC43 and HKU1 and other HCoV which are Severe Acute Respiratory Syndrome (SARS-CoV), Middle East Respiratory Syndrome (MERS-CoV) and COVID-19 (SARS-CoV-2). These HcoV originated as animal infections which then develop and ultimately transmitted to humans. CoV can also be found in animals which are Canine Respiratory Coronavirus (CRCoV), Murine Coronavirus Rat Hepatitis Virus (MHV), Transmissible Gastroenteritis Virus (TGEV), Bovine Coronavirus (BCoV), Feline Coronavirus (FCoV), Canine Coronavirus (CCoV) and Turkey Coronavirus (TCV). CoV has been found to last longer in the atmosphere at lower temperatures and lower relative humidity. Thus, some coronavirus outbreaks can mostly be attributed to cold and dry climates for more effective CoV transmission. Identified CoV are mostly active when the temperature is between $9{ }^{\circ} \mathrm{C}$ and $24^{\circ} \mathrm{C}$. Findings in this review can serve as knowledge and guidance for individuals, related organizations and governments to be prepared for the CoV threats that is currently occurring and that is likely to re-emerge in the coming years. It is also intended to provide useful baseline information for policymakers and the public.
\end{abstract}

KEYWORDS: climatology, coronavirus (CoVs), human coronaviruses (HCoV), meteorology, weather

\section{INTRODUCTION}

Human coronavirus (CoV) history started in 1965, when a virus called B814 was first identified (Tyrrell \& Bynoe, 1966). It is believed that since around the mid-1960s and subsequent years, only two species of human coronavirus namely HCoV-229E and HCoV-OC43 have been identified to have infected humans. Later, members of the coronavirus family novel SARS-CoV were introduced to the human population in 2003 (Van Der Hoek et al., 2006). Human $\mathrm{CoV}$ is considered a virus that only causes the common cold and was never considered a serious public health threat before 2002 (Ashour et al., 2020). However, the emergence of SARS-CoV-1 in 2002 to 2003 changed that perception because this new CoV was the first to infect humans and causes fatality
(Drosten et al., 2003) (Fig. 1). The Coronaviridae is a family of enveloped, positive-strand RNA viruses and especially, human coronaviruses $(\mathrm{HCoV})$, were known to be responsible for a large portion of common colds and upper respiratory tract infections. $\mathrm{HCoV}$ is involved in most of the more serious respiratory diseases paricularly in young children and neonates, the elderly and patients with immunosuppression (Geller et al., 2012). Coronavirus is a positive RNA genome measuring approximately 26-32 kilobases, which is the largest genome known for RNA virus (Weiss \& NavasMartin, 2005). There are four common subtypes of coronavirus that have been reported to have infected humans since 1960 - 2002, namely two alphacoronaviruses (229E and NL63) and two ßetacoronaviruses (OC43 and HKU1). All four of these 
coronaviruses are routinely producing uncomplicated infections of the upper and/or lower respiratory tract (Geller et al., 2012).

Besides covid-19 virus causing the current pandemic since late 2019, there are several outbreaks caused by other coronaviruses such as the severe acute respiratory syndrome (SARS) Coronavirus and Middle East respiratory syndrome (MERS) Coronavirus. SARS-CoV and MERS-CoV are two highly infectious and pathogen viruses that appeared in humans in the early 21 st century (Cui et al., 2019). The first case of SARS was identified on November 16, 2002 starting in southern China (Foshan in Guangdong) (Zhong et al., 2003). SARS has spread rapidly throughout the world with 27 countries being affected and the number of confirmed cases was 8096 and resulted in 774 deaths (World Health Organization, 2004). Ten years later, a highly pathogenic Middle East respiratory syndrome coronavirus (MERS-CoV) has emerged in the Middle Eastern countries (Zaki et al., 2012) including the Korean Peninsula (Habib et al., 2019). MERS-CoV emerged in Saudi Arabia in 2012 with the first case involving one of its citizens in June 2012. The patient suffered from pneumonia and kidney failure resulting in fatal consequences (Farooq et al., 2020). There are approximately 2494 laboratory confirmed cases and 858 deaths reported in 27 countries until November 2019 (World Health Organization, 2019).

In December 2019, several cases of novel Coronavirus (COVID-19) have been identified which began in Wuhan, Hubei Province, China caused by a novel $\beta$-coronavirus. It begins with the discovery of several cases of pneumonia of unknown etiology of people with a history of exposure to the Huanan seafood market (Huang et al., 2020). The cases recorded are linked to the Huanan Seafood Wholesale Market where it sells fish and various other species of live animals including poultry, bats, marmots and snakes (Lu et al., 2020). This virus is also known as a coronavirus of severe acute respiratory syndrome (SARS-CoV-2). The virus can spread very quickly from their origin in Wuhan, Hubei Province, China to countries around the world (Wang et al., 2020a). The Corona virus was said to have spread because of massive human movement in China as they returned to their hometowns to celebrate the Chinese New Year in early 2020. This massive human movement triggered the coronavirus outbreak resulting in a national crisis where it started to spread to other Chinese provinces in early and mid-January 2020. Although a complete travel ban was imposed on all residents of Wuhan on January 23, 2020 the virus still spreads very quickly (Liu et al., 2020).

As of October 15, 2020, there are approximately 214 countries and territories worldwide that have been hit by this virus (Worldometers, 2020). Based on data released by the World Health Organization (WHO), there are 38,002,699 cases of COVID-19 confirmed worldwide until 14 October 2020 while the number of deaths worldwide reached $1,083,234$ cases. Data released by the WHO also indicates that the American region recorded the highest number of confirmed cases at 18,090,384 cases, followed by the South-East Asia region of 8,127,106 confirmed cases, Europe has 7,219,501 confirmed cases, Eastern Mediterranean region charted 2,660,450 confirmed cases, African region recorded 1,240,683 confirmed cases and Western Pacific region has 663,834 confirmed cases (World Health Organization, 2020). This virus is known to be very dangerous and is one of the deadliest viruses in the world. On January 30, 2020 a COVID-19 pandemic was declared by the WHO as a Public Health Emergency of International Concern which poses a high risk to countries with vulnerable health systems (Sohrabi et al., 2020).

\section{AN OVERVIEW OF THE HUMAN AND ANIMAL CORONAVIRUS TYPES}

Coronaviruses belong to the subfamily Coronavirinae within the family of Coronaviridae, under the order Nidovirales (Yang et al., 2020). According to the International Committee of Virus Taxonomy (ICTV), the family Coronaviridae can be classified into two small families namely Letovirinae and Orthocoronavirinae (King et al., 2018). Coronaviruses' size is ranging from 26 to 32 kilobases which is the largest known viral RNA genome (Li et al., 2020). Virion has nucleocapsid consisting of genomic RNA and nucleocapsid protein (N) phosphorylation. It is buried in the phospholipid layer and is protected by a surge glycoprotein (S). Membrane protein (M) which is a type III transmembrane glycoprotein located between the $\mathrm{S}$ proteins in the viral envelope together with envelope protein (E) (Li et al., 2020). All human CoVs are of animal origin (Huynh, 2012; Ithete, 2013; Hu et al., 2017; Hu et al., 2015, Cui et al., 2019).

There are two known genetic and serological groups of Coronavirus that can infect mammals except pigs. The first group consists of the Alphacoronavirus $(\alpha-\mathrm{CoVs})$, and Betacoronavirus ( $\beta-\mathrm{CoVs})$ (MonchatreLeroy et al., 2017), while the second being the Gammacoronavirus (includes viruses of whales and birds) and Deltacoronavirus (includes viruses isolated from pigs and birds) (Harapan et al., 2020). There are two types of $\alpha-\mathrm{CoVs}$ which are $\mathrm{HCoV}-229 \mathrm{E}$ and HCoV-NL63 (Yin \& Wunderink, 2018), while, $\beta$-CoVs can be divided into four lineages namely lineage $\mathrm{B}$ (SARS-CoV and 2019-nCoV) which has about 200 
virus sequences published. Lineage $\mathrm{C}$ includes MERS$\mathrm{CoV}$ which has more than 500 viral sequences (Letko $\&$ Munster, 2020). In the last two decades, two largescale outbreaks of SARS and MERS have occurred due to $\mathrm{CoV}$ (Drosten et al., 2003; Zaki et al., 2012). There are $\beta-\mathrm{CoVs}$ in lineage $\mathrm{A}$ which are $\mathrm{HCoV}-\mathrm{OC} 43$ and HCoV-HKU1 (Yin et al., 2018). SARS-CoV is the coronavirus that causes severe acute respiratory syndrome. The $2019-\mathrm{nCoV}$ is the novel coronavirus that causes coronavirus disease 2019 known as COVID-19, which is now the pandemic, and MERS$\mathrm{CoV}$ is the coronavirus that causes Middle East Respiratory Syndrome. The clinical significance and possibility of $\mathrm{HCoV}$ outbreaks were unknown until the emergence of SARS and MERS outbreaks although $\mathrm{HCoV}$ has been identified for decades (Drosten et al., 2003).

Human coronavirus initially only causes the common cold to its patients. However, severe acute respiratory syndrome (SARS) in 2003 has clearly shown that the emergence of the new human coronavirus has been found to be responsible which in turn makes this coronavirus more recognizable (Weiss et al., 2005). Since the early 1970s, various pathological conditions in domestic animals have been caused by CoV infection (Durham, 1979). It has been identified in a few avian (birds) hosts (Cavanagh, 2007) and can also be on a variety of mammals such as camels, bats, masked palm foxes, mice, dogs and cats (Ismail et al., 2003). Meanwhile, there are a number of animal viruses such as canine respiratory coronavirus $(\mathrm{CRCoV})$ (Weiss et al., 2005) that cause respiratory disease in dogs (Erles et al., 2003), avian infectious bronchitis viruses (IBV) (Weiss et al., 2005) that cause avian infectious bronchitis in chickens (Cavanagh, 2007), and Murine coronavirus rat hepatitis virus (MHV) (Weiss et al., 2005) which can cause a progressive demyelinating encephalitis in mice (Lai \& Cavanagh, 1997). Apart from this, some of the CoV have demonstrated gastrointestinal symptoms such as those transmissible by gastroenteritis virus (TGEV) (Weiss et al., 2005; Pensaert, 1970), bovine coronavirus (BCoV) (Weiss et al., 2005; Bridger et al., 1978), feline coronavirus (FCoV) (Pedersen et al., 1984), canine coronavirus (CCoV) (Binn et al., 1974) and turkey coronavirus (TCV) (Ismail et al., 2003). Coronaviruses are distributed through bat and can also be spread by humans and other animals including birds, cats, dogs, pigs, rats, horses, and whales (Murphy et al., 2012). This shows that coronaviruses not only can be found on humans but the animals as well particularly the mammals and avian (Fig. 2).

The human coronavirus namely strain $229 \mathrm{E}$ was discovered in 1966. It was first discovered when researchers identified five new agents isolated from the human respiratory tract with the common cold (Hamre \& Procknow, 1966). The HCov-229E N protein has a molecular weight of $50 \mathrm{kDa}$ and very basic $(\mathrm{pH}, 10.0)$ exhibiting a strong hydrophilic nature (Toshio et al., 1989). Additionally, this HCoV N protein has around $26 \%-30 \%$ sequence homology with $\mathrm{CoV} \mathrm{N}$ protein from other strains or viruses, such as $\mathrm{HCoV}-\mathrm{OC} 43$ and SARS (Chang et al., 2006). The clinical symptoms of HCov-229E have been identified to include general malaise, headache, nasal discharge, sneezing, sore throat (Tyrrell et al., 1993; Monto, 1974) and, fever and cough (Papa et al., 2007).

HCoV-NL63 has the potential to infect children, the elderly or the infirm and these vulnerable groups will always need hospital treatment due to severe respiratory symptoms (Van Der Hoek et al., 2006). HCoV-NL63 was first isolated in a sevenmonth-old child who was diagnosed with nasopharyngeal aspiration in 2004 in Amsterdam. The child shows some symptoms that indicate a respiratory tract infection, and an X-ray of his chest shows the characteristic features of bronchiolitis (Abdul-Rasool \& Fielding, 2010). HCoV-NL63 occurring in tropical and subtropical regions is highly unlikely to be affected by seasonal differences in its distribution and is not limited only to during winter (Van Der Hoek et al., 2006). This is because, HCoV-NL63 is reported to occur during the spring-summer season in Hong Kong (Chiu et al., 2005) and during the winter in several other countries. HCoV-NL63 was found to be more dominant to spread during winter based on studies in Australia (Arden et al., 2005), Canada (Bastien et al., 2005), Japan (Ebihara et al., 2005), Belgium (Moës et al., 2005), France (Vabret et al., 2005), the Netherlands (Pyrc et al., 2004) and Germany (Van Der Hoek et al., 2005). Children under the age of 1 year and adults with immunocompromised are more likely to suffer from acute respiratory disease caused by HCoV-NL63 (Pyrc et al., 2004).

HCoV-OC43 was first identified in 1967 (McIntosh et al., 1967a; McIntosh et al., 1967b), and it can cause severe respiratory tract disease in children (Jean et al., 2013). HcoV-OC43 RNA has been repeatedly detected in the human brain (Murray et al., 1992). Therefore, HCoV-OC43 has ability in causing persistent infection in human neural cells (Arbour et al., 1999), infect neurons and cause encephalitis (Talbot et al., 2011). Furthermore, HCoV-OC43 could infect human astrocytes and microglia in primary cultures (Bonavia, et al., 1997). HCoV-OC43 RNA was found to be in the cerebrospinal fluid of a child with acute disseminated encephalomyelitis (Yeh et al., 2004). Based on a study conducted by Vabret et al. in 2003, it was found that $\mathrm{HCoV}-\mathrm{OC} 43$ was detected in patients of all age groups with several clinical symptoms such as 
fever, digestive problems, rhinitis, pharyngitis, laryngitis, otitis, bronchitis, bronchiolitis, and pneumonia. In addition, the same study also showed that outbreak of $\mathrm{HCoV}-\mathrm{OC} 43$ respiratory infection was responsible for the symptoms of the lower respiratory tract observed in nearly one-third of patients identified by active surveillance for coronavirus infections (Vabret et al., 2003).

HCoV-HKU1 was identified in Hong Kong in 2005 (Esper et al., 2006; Woo et al., 2005a) when 71year-old patient had been hospitalized with pneumonia and bronchiolitis (Woo et al., 2005a). Patients with HCoV-HKU1 infection have been identified as having respiratory symptoms with dyspnea, cough, and rhinorrhea being the most common (Kanwar et al., 2017). Those who are most at risk of infection by HCoV-HKU1 is the children under the age of 2 years which contributes significantly to the microbial burden among patients with respiratory tract disease during the colder months (Sloots et al., 2006). Mostly, HCoVHKU1 patients will typically develop fever, runny nose, and cough for upper respiratory tract infections, whereas fever, productive cough, and dyspnea are common symptoms for lower respiratory tract infections (Woo et al., 2009). HCoV-HKU1 which is mostly self-limiting infection, with only two deaths were reported in patients with pneumonia caused by this virus (Woo et al., 2005b). CoV-HKU1 infection mainly occurs in autumn and winter and shows that febrile and breakthrough seizures are more common (Lau et al., 2006).

SARS-CoV-1 appeared in 2002-2003 which was also the first deadly $\mathrm{CoV}$ to infect humans (Drosten et al., 2003). There is a similarity of $86 \%$ for the entire SARS-CoV-2 genome occurring in 2019 with SARS-CoV (Chan et al., 2020). Among the similarities are which they are both isolated in bats, originating from a live animal market close to a large and densely human populated area, and has the same main transmission pathway which is through respiratory droplets viral shedding via feces (Wilder-Smith et al., 2020). The median incubation period of SARS-CoV-1 is between 4 and 5 days, and a mean of 4 to 6 days (World Health Organization, 2003). Fever, cough, dyspnea (shortness of breath) and occasionally watery diarrhea are the common symptoms of SARS (De Wit et al., 2016). SARS-CoV belongs to the genus Coronavirus in the family Coronaviridae. SARS-CoV also has a large and positive RNA genome of $27.9 \mathrm{~kb}$ (De Wit et al., 2016). Clinical manifestations of SARS$\mathrm{CoV}-1$ are high fever of $>38^{\circ} \mathrm{C}$, tuberculosis, and rapid progression to respiratory failure (Lee et al., 2003; Booth et al., 2003).

Just as SARS-CoV, the Middle East respiratory syndrome coronavirus (MERS-CoV) also belongs to the genus Coronavirus family Coronaviridae. This MERS-CoV has a slightly larger and positive RNA genome of $30.1 \mathrm{~kb}$ (De Wit et al., 2016) compared to SARS-CoV. MERS-CoV is a novel human pathogen associated with severe respiratory symptoms and renal failure (Bermingham et al., 2012; Zaki et al., 2012). MERS-CoV infection in humans is spread through close contact with infected camels (Memish et al., 2014; Alagaili et al., 2014; Azhar et al., 2014a; Azhar et al., 2014b; Raj et al., 2014), and MERS is caused by human-to-human infection (Assiri et al., 2013). Fig. 3 shows graphic representation of SARS-CoV and MERS-CoV structure and replication. The results of phylogenetic analysis indicate that MERS-CoV belongs to the bat-associated clade 2c $\beta$ coronavirus (Zaki et al., 2012; Van Boheemen et al., 2012). Dromedary camel is the intermediate host for MERS-CoV with the mortality rate of $37 \%$ (Perlman, 2020). Since the detection of MERS-CoV in 2012, it has not been found to have mutated substantially to enhance human infectivity (Forni et al., 2017). MERSCoV belongs to Merbecovirus (Zhu et al., 2020). According to Cui et al. (2019), MERS-CoV may have been present in camels for a long time, perhaps at least 30 years ago. Their findings were confirmed by studies conducted by Müller et al. (2014) where camel serum samples collected in 1983 detected MERS-CoV infection.

The $\beta$-coronavirus novel identified to occur at the end of 2019 (2019-nCoV or the COVID-19) indicated an outbreak reminiscent of severe acute respiratory syndrome SARS-2003 caused by another $\beta$ coronavirus about 17 years ago (Yi-Chia et al., 2020). COVID-19 has some association with SARS-CoV but it is more aggressive than SARS, MERS, or seasonal influenza (Wang et al., 2020a). Studies by Zhou et al. (2020), Ji et al. (202), and Zhang et al. (2020), stated that animals such as bats, snakes and pangolins can be the host for SARS-CoV-2 (Covid-19). Children infected with SARS-CoV-2 mostly showed mild clinical manifestations and recover within 1 to 2 weeks after the disease begins (Shen et al., 2020), while 98\% of COVID-19 adult patients, developed fever (Huang et al., 2020). SARS-CoV-2 (Covid-19) is characterized by rapid human-to-human transmission (Yu et al., 2020; Huang et al., 2020; Paules et al., 2020; Lu et al., 2020; Hui et al., 2020). It was also found that patients who had undergone surgery in the month before being infected with SARS-CoV-2 may be exposed to a higher risk of suffering from clinical severe events than those who did not undergo surgery (Liang et al., 2020). Most deaths caused by Covid-19 are due to multiple organ dysfunction syndrome rather than respiratory failure (Wang et al., 2020a). Normally, SARS-CoV has an 
incubation period of between 2 to 10 days while its median incubation period is between 4 to 7 days (Yang et al., 2020). However, the incubation period for SARS-CoV-2 (Covid-19) appears to be longer, mostly within 14 days, but the median incubation period is shorter at 3 to 4 days (Yang et al., 2020) (Fig. 4).

\section{THE GEOGRAPHY OF COVID-19 AND OTHER CORONAVIRUSES OUTBREAK: Meteorology and Climatology}

Meteorological factors play an important role in the survival or sustainability of viruses and the transmission process of viruses (Tosepu et al., 2020; Braga et al., 2001; Liu et al., 2014; Zanobetti et al., 2002; Fraser et al., 2004; De Almeida Brito et al.,2019; Sagripanti \& Lytle, 2007). Dalziel et al., (2018) \& Wang et al., (2020b), believed that temperature, humidity, and population density can influence viruses' transmissions. Several studies were conducted to prove if there was any significant relationship between temperature and transmission of the virus to severe acute respiratory syndrome (SARS) occurred. According to Yuan et al. (2006), Tan et al. (2005), and Chan et al. (2011), transmission of SARS may occur with the presence of several key factors such as temperature, humidity, and wind speed. A study by Bull in 1980 stated that weather change is highly significantly correlated with changes in mortality due to pneumonia. Similarly, COVID-19 transmission is also significantly related to the influence of temperature and air humidity conditions (Chen et al., 2020). Wang et al., (2020a), also proved that the spreading of COVID-19 was lower in warm and humid regions of China. Meanwhile, MERS is more likely to occur when the climate is rather cold and dry (Gardner et al., 2019).

In mid-March 2020, some researchers from China have stated that there is a link between meteorological factors and the COVID-19 outbreak that is plaguing (Oliveiros et al., 2020; Wang et al., 2020b). It is also supported in studies conducted by Fareed et al., (2020), Iqbal et al. (2020) and Tosepu et al. (2020), which stated that COVID-19 has correlations with temperature, air quality, and other weather conditions. Air quality index (AQI) such as CO (carbon monoxide) and $\mathrm{SO}_{2}$ (sulfur dioxide) in the air and COVID-19 outbreaks were found to have a positive correlation with the total number of infections. If the air quality is poor, then there will be more deaths. The study involved three countries namely Italy, the US, and China (Pansini \& Fornacca, 2020). There is a statistically significant relationship between absolute humidity and average temperature on the spread of
COVID-19 between China territories (Luo et al., 2020). Additionally, the infections of the respiratory pathogens, including the coronavirus is transmitted when rainfall is lower and therefore the relative humidity decreases (Bi et al., 2007). This is because, coronavirus is probably most active when the temperature is between $9{ }^{\circ} \mathrm{C}$ and $24^{\circ} \mathrm{C}$. This is further supported by Zhou et al. (2004) that there is possibility for SARS to decrease in average daily temperature during summer where temperature is higher than $24^{\circ} \mathrm{C}$.

Changes in weather conditions are said to affect the viability and persistence of the virus in the environment and the transmission of MERS itself (Dowell \& Ho, 2004; Lowen et al., 2007). Coronavirus SARS tends to be active in low temperatures and low humidity environments in subtropical regions such as Hong Kong. While, in the tropics that have a high temperature and high relative humidity environment such as in Malaysia, Indonesia, or Thailand causing coronavirus (SARS) to be less active (Chan et al., 2011). SARS disappeared in the warm weather at the end of July (Wallis \& Nerlich, 2005). Since SARS and COVID-19 belonged to the same family and there is likelihood of a similar behavior may occur to COVID19 as well (Wilder-Smith et al., 2020). Bu et al., (2020) stated that constant warm and dry weather is conducive for 2019-nCoV survival. Yuan et al., (2006), showed that biological interactions between SARS viruses and humans also can be caused by variations in temperature and air quality. Therefore, temperature is an important factor in reducing human coronavirus infectivity (Lamarre \& Talbot, 1989). As emphasized by Casanova et al., (2010), the SARS corona virus can survive longer on the surface with relative low humidity and at room temperatures i.e. with air conditioning. Moreover, Chan et al., (2011) found that this SARS corona virus is also able to survive longer on smooth surfaces at higher relative humidity.

Hot and sunny weather will increase the temperature and increase air circulation in the environment. This condition can lead to a reduction in air pollution. Consequently, COVID-19 transmission will also decrease (Kim et al., 1996; Talbot et al., 2005; Medina Ramón et al., 2006; Ko et al., 2007; Wei et al., 2020). This air pollution is associated with excessive respiratory and cardiovascular morbidity (Wong et al., 1999; Atkinson et al., 2001; Wong et al., 2001; Dominici et al., 2006; Medina Ramón et al., 2006; Wellenius et al., 2006; Fusco et al., 2001) and mortality (Wong et al., 2002; Fischer et al., 2003; Ostro et al., 2006; Kan \& Chen, 2003; Pope III et al., 2004). However, it was also found that sunny days and summer caused the population to produce higher vitamin D production. The production of vitamin D can strengthen and improve the function of the immune 
system to overcome Coronavirus infection and other diseases (Oh et al., 2010). Coronavirus can also be associated with the virus that occur seasonally. For instance, bovine coronavirus has an association with winter dysentery of calves (Tråvén et al., 2001; Cho, 2000). Canine coronavirus ( $\mathrm{CCoV})$ survival is longer in infected dog feces during the winter months (Carmichael \& Binn, 1981) which may be due to the influence of lower ambient temperatures (Tennant et al., 1994).

\section{CONCLUSION}

There is a correlation between coronaviruses outbreak with weather, climatology, and meteorology. Thus, the inactivation of $\mathrm{CoV}$ can be influenced by factors such as temperature and humidity that occur due to seasonal differences and climate for an area. Based on all the findings, it is found that rainfall is related to $\mathrm{CoV}$ transmissions, where infections of the respiratory pathogens are transmitted when rainfall is lower. Therefore, climatology and meteorology are important factors in determining the incidence rate of coronaviruses outbreak worldwide. With this knowledge, the government of every country and the medical teams can probably utilize this knowledge base as input in its strategy in suppressing the coronavirus pandemic which may likely to re-emerge in the coming years. It is also intended to provide useful baseline information for policymakers and the public. Knowledge related to the relationship between weather and coronavirus outbreak is also very important considering it can be used to help classify geographic areas at risk in various countries. This is because, every geographical area of countries around the world is different especially in terms of temperature, weather, climate, amount of rain and number of sunny days. Consequently, the number and speed of spread of coronavirus cases in each country is different.

\section{Declaration of Interest Statement}

The authors declare no conflict of interest.

\section{Acknowledgments}

Not applicable.

\section{Funding}

None.

\section{REFERENCES}

1. Abdul-Rasool, S., \& Fielding, B.C. (2010). Understanding Human Coronavirus HCoV-NL63. The open virology journal, 4, 76-84. https://doi.org/10.2174/1874357901004010076.

2. Alagaili, A.N., Briese, T., Mishra, N., Kapoor, V., Sameroff, S.C., de Wit, E., ... \& Epstein, J.H.
(2014). Middle East respiratory syndrome coronavirus infection in dromedary camels in Saudi Arabia. MBio, 5(2), e00884-14.

3. Arbour, N., Côté, G., Lachance, C., Tardieu, M., Cashman, N.R., \& Talbot, P.J. (1999). Acute and persistent infection of human neural cell lines by human coronavirus OC43. Journal of virology, 73(4), 3338-3350.

4. Arden, K.E., Nissen, M.D., Sloots, T.P., \& Mackay, I.M. (2005). New human coronavirus, HCoV-NL63, associated with severe lower respiratory tract disease in Australia. Journal of medical virology, 75(3), 455-462.

5. Ashour, H.M., Elkhatib, W.F., Rahman, M., \& Elshabrawy, H.A. (2020). Insights into the recent 2019 novel coronavirus (SARS-CoV-2) in light of past human coronavirus outbreaks. Pathogens, 9(3), 186.

6. Assiri, A., McGeer, A., Perl, T.M., Price, C. S., Al Rabeeah, A.A., Cummings, D.A., ... \& Madani, $H$. (2013). Hospital outbreak of Middle East respiratory syndrome coronavirus. New England Journal of Medicine, 369(5), 407-416.

7. Atkinson, R.W., Ross Anderson, H., Sunyer, J., Ayres, J.O.N., Baccini, M., Vonk, J.M., ... \& Schwartz, J. (2001). Acute effects of particulate air pollution on respiratory admissions: results from APHEA 2 project. American journal of respiratory and critical care medicine, 164(10), 1860-1866.

8. Azhar, E.I., El-Kafrawy, S.A., Farraj, S.A., Hassan, A.M., Al-Saeed, M.S., Hashem, A.M., \&

9. Madani, T.A. (2014a). Evidence for camel-tohuman transmission of MERS coronavirus. New England Journal of Medicine, 370(26), 2499-2505.

10. Azhar, E.I., Hashem, A.M., El-Kafrawy, S.A., Sohrab, S.S., Aburizaiza, A.S., Farraj, S.A., ... \& Madani, T.A. (2014b). Detection of the Middle East respiratory syndrome coronavirus genome in an air sample originating from a camel barn owned by an infected patient. MBio, 5(4), e01450-14.

11. Bastien, N., Anderson, K., Hart, L., Caeseele, P.V., Brandt, K., Milley, D., \& Li, Y. (2005). Human coronavirus NL63 infection in Canada. The Journal of infectious diseases, 191(4), 503-506.

12. Bermingham, A., Chand, M.A., Brown, C.S., Aarons, E., Tong, C., Langrish, C., ... \& Pebody, R.G. (2012). Severe respiratory illness caused by a novel coronavirus, in a patient transferred to the United Kingdom from the Middle East, September 2012. Eurosurveillance, 17(40), 20290.

13. Bi, P., Wang, J., \& Hiller, J.E. (2007). Weather: driving force behind the transmission of severe acute respiratory syndrome in China? Internal Medicine Journal, 37(8), 550-554.

14. Binn, L.N., Lazar, E.C., Keenan, K.P., Huxsoll, D.L., Marchwicki, R.H., \& Strano, A.J. (1974). Recovery and characterization of a coronavirus from military dogs with diarrhea. In Proceedings, annual meeting of the United States Animal Health Association. 
15. Bonavia, A., Arbour, N., Yong, V.W., \& Talbot, P.J. (1997). Infection of primary cultures of human neural cells by human coronaviruses $229 E$ and OC43. Journal of virology, 71(1), 800-806.

16. Booth, C.M., Matukas, L.M., Tomlinson, G.A., Rachlis, A.R., Rose, D.B., Dwosh, H.A., \& Ephtimios, I.E. (2003). Clinical features and shortterm outcomes of 144 patients with SARS in the greater Toronto area. Jama, 289(21), 2801-2809.

17. Braga, A.L.F., Zanobetti, A., \& Schwartz, J. (2001). The time course of weather-related deaths. Epidemiology, 12(6), 662-667.

18. Bridger, J.C., Caul, E.O., \& Egglestone, S.I. (1978). Replication of an enteric bovine coronavirus in intestinal organ cultures. Archives of virology, 57(1), 43-51.

19. Bull, G.M. (1980). The weather and deaths from pneumonia. The Lancet, 315(8183), 1405-1408.

20. Bu, J., Peng, D.D., Xiao, H., Yue, Q., Han, Y., Lin, Y., ... \& Chen, J. (2020). Analysis of meteorological conditions and prediction of epidemic trend of 2019-nCoV infection in 2020. medRxiv. DOI: https://doi.org/10.1101/2020.02.13.20022715.

21. Carmichael, L.E., \& Binn, L.N. (1981). New enteric viruses in the dog. Advances in Veterinary Science and Comparative Medicine 25, $1-37$.

22. Casanova, L. M., Jeon, S., Rutala, W. A., Weber, D. J., \& Sobsey, M. D. (2010). Effects of air temperature and relative humidity on coronavirus survival on surfaces. Applied and environmental microbiology, 76(9), 2712-2717. https://doi.org/10.1128/AEM.02291-09.

23. Cavanagh, D. (2007). Coronavirus avian infectious bronchitis virus. Veterinary research, 38(2), 281 297.

24. Chan, K.H., Peiris, J.M., Lam, S.Y., Poon, L.L.M., Yuen, K.Y., \& Seto, W.H. (2011). The effects of temperature and relative humidity on the viability of the SARS coronavirus. Advances in virology, 2011.

25. Chan, J.F.W., Kok, K.H., Zhu, Z., Chu, H., To, K.K.W., Yuan, S., \& Yuen, K.Y. (2020). Genomic characterization of the 2019 novel humanpathogenic coronavirus isolated from a patient with atypical pneumonia after visiting Wuhan. Emerging microbes \& infections, $\quad 9(1), \quad 221$ 236.

26. Chang, C.K., Sue, S.C., Yu, T.H., Hsieh, C.M., Tsai, C.K., Chiang, Y.C., \& Lin, C.H. (2006). Modular organization of SARS coronavirus nucleocapsid protein. Journal of biomedical science, 13(1), 59-72.

27. Chen, B., Liang, H., Yuan, X., Hu, Y., Xu, M., Zhao, $Y ., \ldots \&$ \&hu, X. (2020). Roles of meteorological conditions in COVID-19 transmission on a worldwide scale. MedRxiv.

28. Chiu, S.S., Hung Chan, K., Wing Chu, K., Kwan, S.W., Guan, Y., Man Poon, L.L., \& Peiris, J. S.M. (2005). Human coronavirus NL63 infection and other coronavirus infections in children hospitalized with acute respiratory disease in Hong Kong, China. Clinical infectious diseases, 40(12), 1721-1729.

29. Cho, K.O., Halbur, P.G., Bruna, J.D., Sorden, S.D., Yoon, K.J., Janke, B.H., ... \& Saif, L.J. (2000). Detection and isolation of coronavirus from feces of three herds of feedlot cattle during outbreaks of winter dysentery-like disease. Journal of the American Veterinary Medical Association, 217(8), 1191-1194.

30. Cui, J., Li, F., \& Shi, Z.L. (2019). Origin and evolution of pathogenic coronaviruses. Nature reviews. Microbiology, 17(3), 181-192. https://doi.org/10.1038/s41579-018-0118-9.

31. Dalziel, B.D., Kissler, S., Gog, J.R., Viboud, C., Bjørnstad, O.N., Metcalf, C.J.E., \& Grenfell, B.T. (2018). Urbanization and humidity shape the intensity of influenza epidemics in US cities. Science, 362(6410), 75-79.

32. De Almeida Brito, A., de Araújo, H.A., \& Zebende, G.F. (2019). Detrended Multiple Cross Correlation Coefficient applied to solar radiation, air temperature and relative humidity. Scientific Reports, 9(1), 1-10.

33. De Wit, E., Van Doremalen, N., Falzarano, D., \& Munster, V.J. (2016). SARS and MERS: recent insights into emerging coronaviruses. Nature Reviews Microbiology, 14(8), 523.

34. Dominici, F., Peng, R.D., Bell, M.L., Pham, L., McDermott, A., Zeger, S.L., \& Samet, J.M. (2006). Fine particulate air pollution and hospital admission for cardiovascular and respiratory diseases. Jama, 295(10), 1127-1134.

35. Dowell, S.F., \& Ho, M.S. (2004). Seasonality of infectious diseases and severe acute respiratory syndrome-what we don't know can hurt us. The Lancet infectious diseases, 4(11), 704708.

36. Drosten, C., Günther, S., Preiser, W., Van Der Werf, S., Brodt, H.R., Becker, S., ... \& Berger, A. (2003). Identification of a novel coronavirus in patients with severe acute respiratory syndrome. New England journal of medicine, 348(20), 1967-1976.

37. Durham, P.J.K., Stevenson, B.A., \& Farquharson, B.C. (1979). Rotavirus and coronavirus associated diarrhoea in domestic animals. New Zealand Veterinary Journal, 27(3), 30-32.

38. Ebihara, T., Endo, R., Ma, X., Ishiguro, N., \& Kikuta, H. (2005). Detection of human coronavirus NL63 in young children with bronchiolitis. Journal of medical virology, 75(3), 463-465.

39. Erles, K., Toomey, C., Brooks, H.W., \& Brownlie, J. (2003). Detection of a group 2 coronavirus in dogs with canine infectious respiratory disease. Virology, 310(2), 216-223.

40. Esper, F., Weibel, C., Ferguson, D., Landry, M.L., \& Kahn, J.S. (2006). Coronavirus HKU1 Infection in the United States. Emerging Infectious Diseases, 
12(5), 775-779. $\quad$ https:// dx.doi.org/10.3201/eid1205.051316.

41. Fareed, Z., Iqbal, N., Shahzad, F., Shah, S.G.M., Zulfiqar, B., Shahzad, K., ... \& Shahzad, U. (2020). Co-variance nexus between COVID-19 mortality, humidity, and air quality index in Wuhan, China: New insights from partial and multiple wavelet coherence. Air Quality, Atmosphere \& Health, 13:673-682. DOI:https://doi.org/10.1007/s11869-020-00847-

42. Farooq, H. Z., Davies, E., Ahmad, S., Machin, N., Hesketh, L., Guiver, M., \& Turner, A. J. (2020). Middle East respiratory syndrome coronavirus (MERS-CoV)-Surveillance and testing in North England from 2012 to 2019. International Journal of Infectious Diseases.

43. Fischer, P., Hoek, G., Brunekreef, B., Verhoeff, A., \& Van Wijnen, J. (2003). Air pollution and mortality in The Netherlands: are the elderly more at risk?. European respiratory journal, 21(40 suppl), $34 s-38 s$.

44. Forni, D., Cagliani, R., Clerici, M., \& Sironi, M. (2017). Molecular evolution of human coronavirus genomes. Trends in microbiology, 25(1), 35-48.

45. Fraser, C., Riley, S., Anderson, R.M., \& Ferguson, N.M. (2004). Factors that make an infectious disease outbreak controllable. Proceedings of the National Academy of Sciences, 101(16), 6146-6151.

46. Fusco, D., Forastiere, F., Michelozzi, P., Spadea, T., Ostro, B., Arca, M., \& Perucci, C.A. (2001). Air pollution and hospital admissions for respiratory conditions in Rome, Italy. European respiratory journal, 17(6), 1143-1150.

47. Gardner, E.G., Kelton, D., Poljak, Z., Van Kerkhove, M., Von Dobschuetz, S., \& Greer, A.L. (2019). A case-crossover analysis of the impact of weather on primary cases of Middle East respiratory syndrome. BMC infectious diseases, 19(1), 1-10.

48. Geller, C., Varbanov, M., \& Duval, R.E. (2012). Human coronaviruses: insights into environmental resistance and its influence on the development of new antiseptic strategies. Viruses, 4(11), 30443068.

49. Habib, A.M.G., Ali, M.A.E., Zouaoui, B.R., Taha, M.A.H., Mohammed, B.S., \& Saquib, N.(2019). Clinical outcomes among hospital patients with Middle East respiratory syndrome coronavirus (MERS-CoV) infection. BMC Infectious Diseases 19, (870). Htt ps://doi.org/10.1186/s12879-0194555-5.

50. Hamre, D., \& Procknow, J.J. (1966). A new virus isolated from the human respiratory tract. Proceedings of the Society for Experimental Biology and Medicine, 121(1), 190-193.

51. Harapan, H., Itoh, N., Yufika, A., Winardi, W., Keam, S., Te, H., \& Mudatsir, M. (2020). Coronavirus disease 2019 (COVID-19): A literature review. Journal of Infection and

\section{Public}

Health. doi:10.1016/j.jiph.2020.03.019.

52. Huang, C., Wang, Y., Li, X., Ren, L., Zhao, J., Hu, Y., Zhang, L., Fan, G., Xu, J., Gu, X., Cheng, Z., Yu, T., Xia, J., Wei, Y., Wu, W., Xie, X., Yin, W., Li, H., Liu, M., Xiao, Y., ... Cao, B. (2020). Clinical features of patients infected with 2019 novel coronavirus in Wuhan, China. Lancet (London, England), $\quad 395(10223), \quad$ 497-506. https://doi.org/10.1016/S0140 6736(20)30183-5.

53. Hu, B., Ge, X., Wang, L.F., \& Shi, Z. (2015). Bat origin of human coronaviruses. Virology journal, 12(1), 1-10.

54. Hu, B., Zeng, L.P., Yang, X.L., Ge, X. Y., Zhang, W., Li, B., ... \& Luo, D.S. (2017). Discovery of a rich gene pool of bat SARS-related coronaviruses provides new insights into theorigin of SARS coronavirus. PLoS pathogens, 13(11), e1006698.

55. Hui, D.S., Azhar, E.I., Madani, T.A., Ntoumi, F., Kock, R., Dar, O., ... \& Zumla, A. (2020). The continuing 2019-nCoV epidemic threat of novel coronaviruses to global health-The latest 2019 novel coronavirus outbreak in Wuhan, China. International Journal of Infectious Diseases, 91, 264-266.

56. Huynh, J., Li, S., Yount, B., Smith, A., Sturges, L., Olsen, J.C., ... \& Frieman, M.B. (2012). Evidence supporting a zoonotic origin of human coronavirus strain NL63. Journal of virology, 86(23), 1281612825.

57. Iqbal, N., Fareed, Z., Shahzad, F., He, X., Shahzad, U., \& Lina, M. (2020). Nexus between COVID-19, temperature and exchange rate in Wuhan City: New findings from Partial and Multiple Wavelet Coherence. Science of the Total Environment, 138916. DOI: https://doi.org/10.1016/j.scitotenv.2020.138916.

58. Ismail, M.M., Tang, Y., \& Saif, Y.M. (2003). Pathogenicity of turkey coronavirus in turkeys and chickens. Avian diseases, 47(3), 515-522.

59. Ithete, N.L., Stoffberg, S., Corman, V.M., Cottontail, V.M., Richards, L.R., Schoeman, M.C., ... \& Preiser, W. (2013). Close relative of human Middle East respiratory syndrome coronavirus in bat, South Africa. Emerging infectious diseases, 19(10), 1697.

60. Jean, A., Quach, C., Yung, A., \& Semret, M. (2013). Severity and outcome associated with human coronavirus OC43 infections among children. The Pediatric infectious disease journal, 32(4), 325329.

61. Ji, W., Wang, W., Zhao, X., Zai, J., \& Li, X. (2020). Cross-species transmission of the newly identified coronavirus 2019-nCoV. Journal of medical virology, 92(4), 433-440.

62. Kan, H., \& Chen, B. (2003). Air pollution and daily mortality in Shanghai: a time-series study. Archives of Environmental \& Occupational Health, 58(6), 360 . 
63. Kanwar, A., Selvaraju, S., \& Esper, F. (2017). Human coronavirus-HKU1 infection among adults in Cleveland, Ohio. In Open forum infectious diseases (Vol. 4, No. 2). Oxford University Press.

64. Kim, P.E., Musher, D.M., Glezen, W.P., Barradas, M.C.R., Nahm, W.K., \& Wright, C.E. (1996). Association of invasive pneumococcal disease with season, atmospheric conditions, air pollution, and the isolation of respiratory viruses. Clinical infectious diseases, 22(1), 100-106.

65. King, A.M., Lefkowitz, E.J., Mushegian, A.R., Adams, M.J., Dutilh, B.E., Gorbalenya, A.E., ... \& Kropinski, A.M. (2018). Changes to taxonomy and the International Code of Virus Classification and Nomenclature ratified by the International Committee on Taxonomy of Viruses (2018). Archives of virology, 163(9), 2601-2631.

66. Ko, F.W., Tam, W., Wong, T.W., Chan, D.P., Tung, A.H., Lai, C.K., \& Hui, D.S. (2007). Temporal relationship between air pollutants and hospital admissions for chronic obstructive pulmonary disease in Hong Kong. Thorax, 62(9), 780-785.

67. Lai, M.M., \& Cavanagh, D. (1997). The molecular biology of coronaviruses. In Advances in virus research (Vol. 48, pp. 1-100). Academic Press.

68. Lamarre, A., \& Talbot, P.J. (1989). Effect of $p H$ and temperature on the infectivity of human coronavirus 229E. Canadian journal of microbiology, 35(10), 972-974.

69. Lau, S.K., Woo, P.C., Yip, C.C., Tse, H., Tsoi, H.W., Cheng, V.C., \& So, L.Y. (2006). Coronavirus HKU1 and other coronavirus infections in Hong Kong. Journal of clinical microbiology, 44(6), 2063-2071.

70. Lee, N., Hui, D., Wu, A., Chan, P., Cameron, P., Joynt, G.M., ... \& Lui, S.F. (2003). A major outbreak of severe acute respiratory syndrome in Hong Kong. New England Journal of Medicine, 348(20), 1986-1994.

71. Letko, M., \& Munster, V. (2020). Functional assessment of cell entry and receptor usage for lineage $B \quad \beta$-coronaviruses, including 2019-nCoV. BioRxiv: the preprint server for biology, 2020.01.22.915660. https://doi.org/10.1101/2020.01.22.915660.

72. Li, G., Fan, Y., Lai, Y., Han, T., Li, Z., Zhou, P., ... \& Zhang, $Q$. (2020). Coronavirus infections and immune responses. Journal of medical virology, 92(4), 424-432.

73. Liang, W., Guan, W., Chen, R., Wang, W., Li, J., $X u, K ., \ldots \&$ \&i, S. (2020). Cancer patients in SARS-CoV-2 infection: a nationwide analysis in China. The Lancet Oncology, 21(3), 335-337.

74. Liu, Y., Kan, H., Xu, J., Rogers, D., Peng, L., Ye, X., ... \& Wang, W. (2014). Temporal relationship between hospital admissions for pneumonia and weather conditions in Shanghai, China: a timeseries analysis. BMJ open, 4(7).

75. Liu, H., Manzoor, A., Wang, C., Zhang, L., \& Manzoor, Z. (2020). The COVID-19 outbreak and affected countries stock markets response. International Journal of Environmental Research and Public Health, 17(8), 2800.

76. Lowen, A.C., Mubareka, S., Steel, J., \& Palese, P. (2007). Influenza virus transmission is dependent on relative humidity and temperature. PLOS Pathog, 3(10), e151.

77. Lu, H., Stratton, C.W., \& Tang, Y.W. (2020). Outbreak of pneumonia of unknown etiology in Wuhan, China: The mystery and the miracle. Journal of medical virology, 92(4), 401402.

78. Luo, W., Majumder, M., Liu, D., Poirier, C., Mandl, K., Lipsitch, M., \& Santillana, M. (2020). The role of absolute humidity on transmission rates of the COVID-19 outbreak. DOI: https://doi.org/10.1101/2020.02.12.20022467.

79. McIntosh, K., Becker, W.B., \& Chanock, R.M. (1967a). Growth in suckling-mouse brain of" IBV-like" viruses from patients with upper respiratory tract disease. Proceedings of the National Academy of Sciences of the United States of America, 58(6), 2268.

80. McIntosh, K., Dees, J.H., Becker, W.B., Kapikian, A.Z., \& Chanock, R.M. (1967b). Recovery in tracheal organ cultures of novel viruses from patients with respiratory disease. Proceedings of the National Academy of Sciences of the United States of America, 57(4), 933.

81. Medina-Ramon, M., Zanobetti, A., \& Schwartz, J. (2006). The effect of ozone and PM10 on hospital admissions for pneumonia and chronic obstructive pulmonary disease: a national multicity study. American journal of epidemiology, 163(6), 579-588.

82. Memish, Z.A., Cotten, M., Meyer, B., Watson, S.J., Alsahafi, A.J., Al Rabeeah, A.A., ... \& Al Masri, M. (2014). Human infection with MERS coronavirus after exposure to infected camels, Saudi Arabia, 2013. Emerging infectious diseases, 20(6), 1012.

83. Moёs, E., Vijgen, L., Keyaerts, E., Zlateva, K., Li, S., Maes, P., \& Van Ranst, M. (2005). A novel pancoronavirus $R T-P C R$ assay: frequent detection of human coronavirus NL63 in children hospitalized with respiratory tract infections in Belgium. BMC infectious diseases, 5(1), 6.

84. Monchatre-Leroy, E., Boué, F., Boucher, J.M., Renault, C., Moutou, F., Ar Gouilh, M., \& Umhang, $G$. (2017). Identification of alpha and beta coronavirus in wildlife species in France: bats, rodents, rabbits, and hedgehogs. Viruses, 9(12), 364.

85. Monto, A. S. (1974). Medical reviews. Coronaviruses. The Yale journal of biology and medicine, 47(4), 234.

86. Müller, M.A., Corman, V.M., Jores, J., Meyer, B., Younan, M., Liljander, A., ... \& Bornstein, $S$. (2014). MERS coronavirus neutralizing antibodies in camels, Eastern Africa, 1983-1997. Emerging infectious diseases, 20(12), 2093. 
87. Murphy, F.A., Fauquet, C.M., Bishop, D.H., Ghabrial, S.A., Jarvis, A.W., Martelli, G.P., ... \& Summers, M.D. (Eds.). (2012). Virus taxonomy: classification and nomenclature of viruses (Vol. 10). Springer Science \& Business Media.

88. Murray, R.S., Brown, B., Brain, D., \& Cabirac, G.F. (1992). Detection of coronavirus RNA and antigen in multiple sclerosis brain. Annals of Neurology: Official Journal of the American Neurological Association and the Child Neurology Society, 31(5), 525-533.

89. Oh, E.Y., Ansell, C., Nawaz, H., Yang, C.H., Wood, P.A., \& Hrushesky, W.J. (2010). Global breast cancer seasonality. Breast cancer research and treatment, 123(1), 233-243.

90. Oliveiros, B., Caramelo, L., Ferreira, N.C., \& Caramelo, F. (2020). Role of temperature and humidity in the modulation of the doubling time of COVID-19 cases. medRxiv. Doi: https://doi.org/10.1101/2020.03.05.20031872.

91. Ostro, B., Broadwin, R., Green, S., Feng, W.Y., \& Lipsett, M. (2006). Fine particulate air pollution and mortality in nine California counties: results from CALFINE. Environ Health Perspect 114: 2933.

92. Pansini, R., \& Fornacca, D. (2020). COVID-19 higher induced mortality in Chinese regions with lower air quality. DOI, 10(2020.04), 04-20053595.

93. Papa, A., Papadimitriou, E., Luna, L.K., Al Masri, M., Souliou, E., Eboriadou, M., Antoniadis, A., \& Drosten, C. (2007). Coronaviruses in children, Greece. Emerging infectious diseases, 13(6), 947949. https://doi.org/10.3201/eid1306.061353.

94. Paules, C.I., Marston, H.D., \& Fauci, A.S. (2020). Coronavirus infections-more than just the common cold. Jama, 323(8), 707-708.

95. Perlman, S. (2020). Another decade, another coronavirus. N Engl J Med 2020; 382:760-762. DOI: 10.1056/NEJMe2001126.

96. Pensaert, M., Haelterman, E.O., \& Hinsman, E.J. (1970). Transmissible gastroenteritis of swine: virus-intestinal cell interactions II. Electron microscopy of the epithelium in isolated jejunal loops. Archiv für die gesamte Virusforschung, 31(34), 335-351.

97. Pedersen, N.C., Evermann, J.F., McKeirnan, A.J., \& Ott, R.L. (1984). Pathogenicity studies of feline coronavirus isolates 79-1146 and 79-1683. American journal of veterinary research, 45(12), 2580-2585.

98. Pope III, C.A., Burnett, R.T., Thurston, G.D., Thun, M.J., Calle, E.E., Krewski, D., \& Godleski, J.J. (2004). Cardiovascular mortality and long-term exposure to particulate air pollution: epidemiological evidence of general pathophysiological pathways of disease. Circulation, 109(1), 71-77.

99. Pyrc, K., Jebbink, M.F., Vermeulen-Oost, W., Berkhout, R.J., Wolthers, K.C., Wertheim-van, P.D., \& Berkhout, B. (2004). Identification of a new human coronavirus. Nature medicine, 10(4), 368373.

100. Raj, V.S., Farag, E.A., Reusken, C.B., Lamers, M.M., Pas, S.D., Voermans, J., ... \& AlHajri, M. M. (2014). Isolation of MERS coronavirus from a dromedary camel, Qatar, 2014. Emerging infectious diseases, 20(8), 1339.

101. Sagripanti, J.L., \& Lytle, C.D. (2007). Inactivation of influenza virus by solar radiation. 1278-1282.

Photochemistry and photobiology, 83(5),

102. Shen, K., Yang, Y., Wang, T., Zhao, D., Jiang, Y., Jin, R., ... \& Shang, Y. (2020). Diagnosis, treatment, and prevention of 2019 novel coronavirus infection in children: experts' consensus statement. World journal of pediatrics, 1-9.

103. Sloots, T.P., McErlean, P., Speicher, D.J., Arden, K.E., Nissen, M.D., \& Mackay, I.M. (2006). Evidence of human coronavirus HKU1 and human bocavirus in Australian children. Journal of clinical virology, 35(1), 99-102.

104. Sohrabi, C., Alsafi, Z., O'Neill, N., Khan, M., Kerwan, A., Al-Jabir, A., Iosifidis, C., \& Agha, R. (2020). World Health Organization declares global emergency: A review of the 2019 novel coronavirus (COVID-19). International journal of surgery (London, England), 76, $71-76$.

https://doi.org/10.1016/j.ijsu.2020.02.034.

105. Talbot, T.R., Poehling, K.A., Hartert, T.V., Arbogast, P.G., Halasa, N.B., Edwards, K.M., ... \& Griffin, M.R. (2005). Seasonality of invasive pneumococcal disease: temporal relation to documented influenza and respiratory syncytial viral circulation. The American journal of medicine, 118(3), 285-291.

106. Talbot, P.J., Desforges, M., Brison, E., Jacomy, H., \& Tkachev, S. (2011). Coronaviruses as encephalitis-inducing infectious agents. Nonflavirus Encephalitis. In-Tech, 185-202.

107. Tan, J., Mu, L., Huang, J., Yu, S., Chen, B., \& Yin, $J$. (2005). An initial investigation of the association between the SARS outbreak and weather: with the view of the environmenta temperature and its variation. Journal of Epidemiology \& Community Health, 59(3), 186-192.

108. Tennant, B.J., Gaskell, R.M., \& Gaskell, C.J. (1994). Studies on the survival of canine coronavirus under different environmental conditions. Veterinary microbiology, 42(2-3), 255259.

109. Tosepu, R., Gunawan, J., Effendy, D.S., Lestari, H., Bahar, H., \& Asfian, P. (2020). Correlation between weather and Covid-19 pandemic in Jakarta, Indonesia. Science of the Total Environment, $138436 . \quad$ DOI: https://doi.org/10.1016/j.scitotenv.2020.138436.

110. Toshio, K., Soe, L.H., \& Lai, M.M. (1989). Sequence analysis of nucleocapsid gene and leader 
RNA of human coronavirus OC43. Virus research, 12(1), 1-9.

111. Tråvén, M., Näslund, K., Linde, N., Linde, B., Silvan, A., Fossum, C., ... \& Larsson, B. (2001). Experimental reproduction of winter dysentery in lactating cows using BCV comparison with $B C V$ infection in milk-fed calves. Veterinary microbiology, 81(2), 127-151.

112. Tyrrell, D.A.J., Cohen, S., \& Schilarb, J.E. (1993). Signs and symptoms in common colds. Epidemiology \& Infection, 111(1), 143-156.

113. Tyrrell, D.A., \& Bynoe, M.L. (1966). Cultivation of viruses from a high proportion of patients with colds. Lancet (London, England), 1(7428), 76-77. https://doi.org/10. 1016/s 01406736(66)92364-6.

114. Vabret, A., Mourez, T., Gouarin, S., Petitjean, J., \& Freymuth, F. (2003). An outbreak of coronavirus OC43 respiratory infection in Normandy, France. Clinical infectious diseases, 36(8), 985-989.

115. Vabret, A., Mourez, T., Dina, J., Van Der Hoek, L., Gouarin, S., Petitjean, J., \& Freymuth, F. (2005). Human coronavirus NL63, France. Emerging infectious diseases, 11(8), 1225.

116. Van Boheemen, S., de Graaf, M., Lauber, C., Bestebroer, T.M., Raj, V.S., Zaki, A.M., .. \& Fouchier, R.A. (2012). Genomic characterization of a newly discovered coronavirus associated with acute respiratory distress syndrome in humans. MBio, 3(6).

117. Van Der Hoek, L., Sure, K., Ihorst, G., Stang, A., Pyrc, K., Jebbink, M. F., \& Überla, K. (2005). Croup is associated with the novel coronavirus NL63. PLoS Med, 2(8), e240.

118. Van Der Hoek, L., Pyrc, K., \& Berkhout, B. (2006). Human coronavirus NL63, a new respiratory virus. FEMS microbiology reviews, 30(5), 760-773.

119. Wallis, P., \& Nerlich, B. (2005). Disease metaphors in new epidemics: the UK media framing of the 2003 SARS epidemic. Social science \& medicine, 60(11), 2629-2639.

120. Wang, C., Horby, P.W., Hayden, F.G., \& Gao, G.F. (2020a). A novel coronavirus outbreak of global health concern. Lancet (London, England), 395(10223), 470-473. https://doi.org 110.1016/S01406736(20)30185-9.

121. Wang, J., Tang, K., Feng, K., \& Lv, W. (2020b). High temperature and high humidity reduce the transmission of COVID-19. Available at SSRN 3551767.

122. Wei, M., Liu, H., Chen, J., Xu, C., Li, J., Xu, P., \& Sun, Z. (2020). Effects of aerosol pollution on PM2. 5-associated bacteria in typical inland and coastal cities of northern China during the winter heating season. Environmental Pollution, 262, 114188.

123. Weiss, S.R., \& Navas-Martin, S. (2005). Coronavirus pathogenesis and the emerging pathogen severe acute respiratory syndrome coronavirus. Microbiology and molecular biology reviews, 69(4), 635-664.
124. Wellenius, G.A., Schwartz, J., \& Mittleman, M.A. (2006). Particulate air pollution and hospital admissions for congestive heart failure in seven United States cities. The American journal of cardiology, 97(3), 404-408.

125. Wilder-Smith, A., Chiew, C. J., \& Lee, V.J. (2020). Can we contain the COVID-19 outbreak with the same measures as for SARS?.

The Lancet Infectious Diseases. DOI:https://doi.or g/10.1016/S1473-3099(20)30129-8.

126. Wong, T.W., Lau, T.S., Yu, T.S., Neller, A., Wong, S.L., Tam, W., \& Pang, S.W. (1999). Air pollution and hospital admissions for respiratory and cardiovascular diseases in Hong Kong. Occupational and environmental medicine, 56(10), 679-683.

127. Wong, G.W.K., Ko, F.W.S., Lau, T.S., Li, S.T., Hui, D., Pang, S.W., ... \& Lai, C.K.W. (2001). Temporal relationship between air pollution and hospital admissions for asthmatic children in Hong Kong. Clinical \& Experimental Allergy, 31(4), 565-569.

128. Wong, T.W., Tam, W.S., Yu, T.S., \& Wong, A.H.S. (2002). Associations between daily mortalities from respiratory and cardiovascular diseases and air pollution in Hong Kong, China. Occupational and environmental medicine, 59(1), 30-35.

129. Woo, P.C., Lau, S.K., Chu, C.M., Chan, K.H., Tsoi, H.W., Huang, Y., \& Poon, L.L. (2005a). Characterization and complete genome sequence of a novel coronavirus, coronavirus HKU1, from patients with pneumonia. Journal of virology, 79(2), 884-895.

130. Woo, P.C., Lau, S.K., Tsoi, H.W., Huang, Y., Poon, R.W., Chu, C.M., \& Cheng, V.C. (2005b). Clinical and molecular epidemiological features of coronavirus HKU1-associated communityacquired pneumonia. The Journal of infectious diseases, 192(11), 1898-1907.

131. Woo, P.C., Lau, S.K., Yip, C.C., Huang, Y., \& Yuen, K.Y. (2009). More and more coronaviruses: human coronavirus HKU1. Viruses, 1(1), 57-71.

132. World Health Organization. (2003). Consensus document on the epidemiology of severe acute respiratory syndrome (SARS) (No. WHO/CDS/CSR/GAR/2003.11). World Health Organization.

133. World Health Organization. (2004). WHO SARS risk assessment and preparedness framework (No. WHO/CDS/CSR/ARO/2004.2). World Health Organization.

134. World Health Organization. (2019). Middle East respiratory syndrome coronavirus (MERS CoV). Accessed October 16, 2020 retrieved from https://www.who.int/emergenci es/merscov/en/.

135. World Health Organization. (2020). WHO Coronavirus Disease (COVID-19) Dashboard. Accessed October 15, 2020 retrieved from https://covid19.who.int/. 
136. Worldometers. (2020). Countries where COVID-19 has spread. Accessed October 15, 2020 retrieved from

https://www.worldometers.info/coronavirus/countri es-where-corona virushas-spread/.

137. Yang, Y., Xiao, Z., Ye, K., He, X., Sun, B., Qin, Z., ... \& Zhao, W. (2020). SARS-CoV-2: characteristics and current advances in research. Virology journal, 17(1), 1-17. DOI: https://doi.org/10.1186/s12985020-01369-z.

138. Yi-Chia, W., Ching-Sunga, C., Yu-Jiuna, C. (2020). The outbreak of COVID-19: An overview, Journal of the Chinese Medical Association: 83(3), pp, 217-220 doi: 10.1097/JCMA.00 00000000000270.

139. Yeh, E.A., Collins, A., Cohen, M.E., Duffner, P.K., \& Faden, H. (2004). Detection of coronavirus in the central nervous system of a child with acute disseminated encephalomyelitis. Pediatrics, 113(1), e73-e76.

140. Yin, Y., \& Wunderink, R.G. (2018). MERS, SARS and other coronaviruses as causes of pneumonia. Respirology, 23(2), 130-137.

141. Yu, J., Ouyang, W., Chua, M.L., \& Xie, C. (2020). SARS-CoV-2 transmission in cancer patients of a tertiary hospital in Wuhan. medRxiv.

142. Yuan, J., Yun, H., Lan, W., Wang, W., Sullivan, S.G., Jia, S., \& Bittles, A.H. (2006). A climatologic investigation of the SARS-CoV outbreak in Beijing, China. American journal of infection control, 34(4), 234-236.

143. Zaki, A.M., Van Boheemen, S., Bestebroer, T.M., Osterhaus, A.D., \& Fouchier, R.A. (2012). Isolation of a novel coronavirus from a man with pneumonia in Saudi Arabia. New England Journal of Medicine, 367(19), 1814-1820.

144. Zanobetti, A., Schwartz, J., Samoli, E., Gryparis, A., Touloumi, G., Atkinson, R., ... \& Forsberg, $B$. (2002). The temporal pattern of mortality responses to air pollution: a multicity assessment of mortality displacement. Epidemiology, 13(1), 87-93.

145. Zhang, Z., Wu, Q., \& Zhang, T. (2020). Pangolin homology associated with 2019-nCoV. bioRxiv. doi: https://doi.org/10.1101/2020.02.19.950253.

146. Zhong, N.S., Zheng, B.J., Li, Y.M., Poon, L.L.M., Xie, Z.H., Chan, K.H., \& Liu, X.Q. (2003). Epidemiology and cause of severe acute respiratory syndrome (SARS) in Guangdong, People's Republic of China, in February, 2003. The Lancet, 362(9393), 1353-1358.

147. Zhou, Z.X., \& Jiang, C.Q. (2004). Effect of environment and occupational hygiene factors of hospital infection on SARS outbreak. Zhonghua lao dong wei sheng zhi ye bing za zhi = Zhonghua laodong weisheng zhiyebing zazhi = Chinese journal of industrial hygiene and occupational diseases, 22(4), 261-263.

148. Zhou, P., Yang, X.L., Wang, X.G., Hu, B., Zhang, L., ... \& Shi, Z.L. (2020). Discovery of a novel coronavirus associated with the recent pneumonia outbreak in humans and its potential bat origin. BioRxiv. Nature doi: 10.1038/s41586-020-2012-7.

149. Zhu, N., Zhang, D., Wang, W., Li, X., Yang, B., Song, J., ... \& Niu, P. (2020). A novel coronavirus from patients with pneumonia in China, 2019. New England Journal of Medicine 2020; 382:727-733. DOI: 10.1056/NEJMoa2001017.

\section{LIST OF FIGURES}

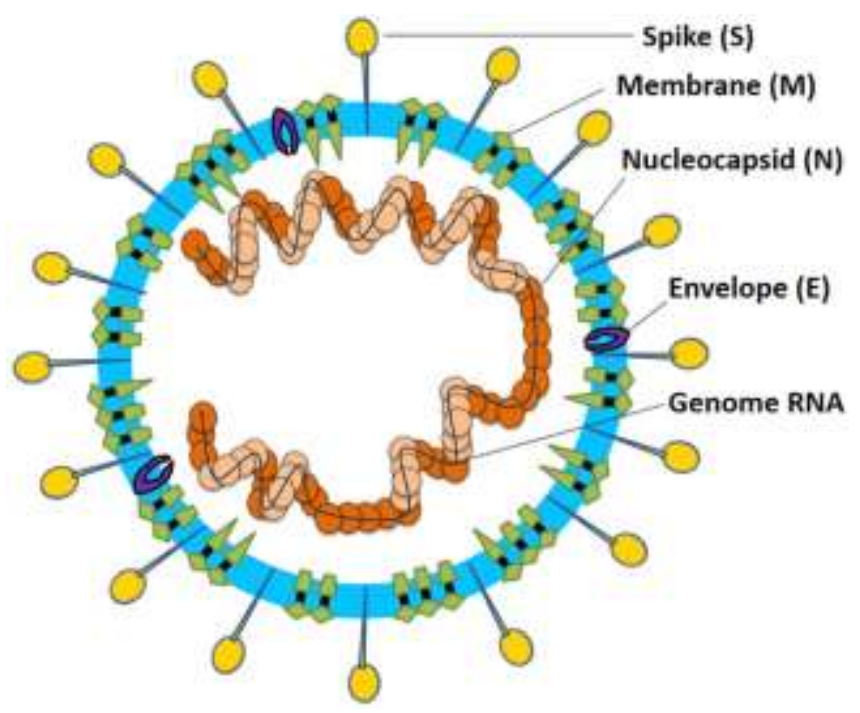

Fig. 1. Structure of CoV virion (Li et al., 2020) 


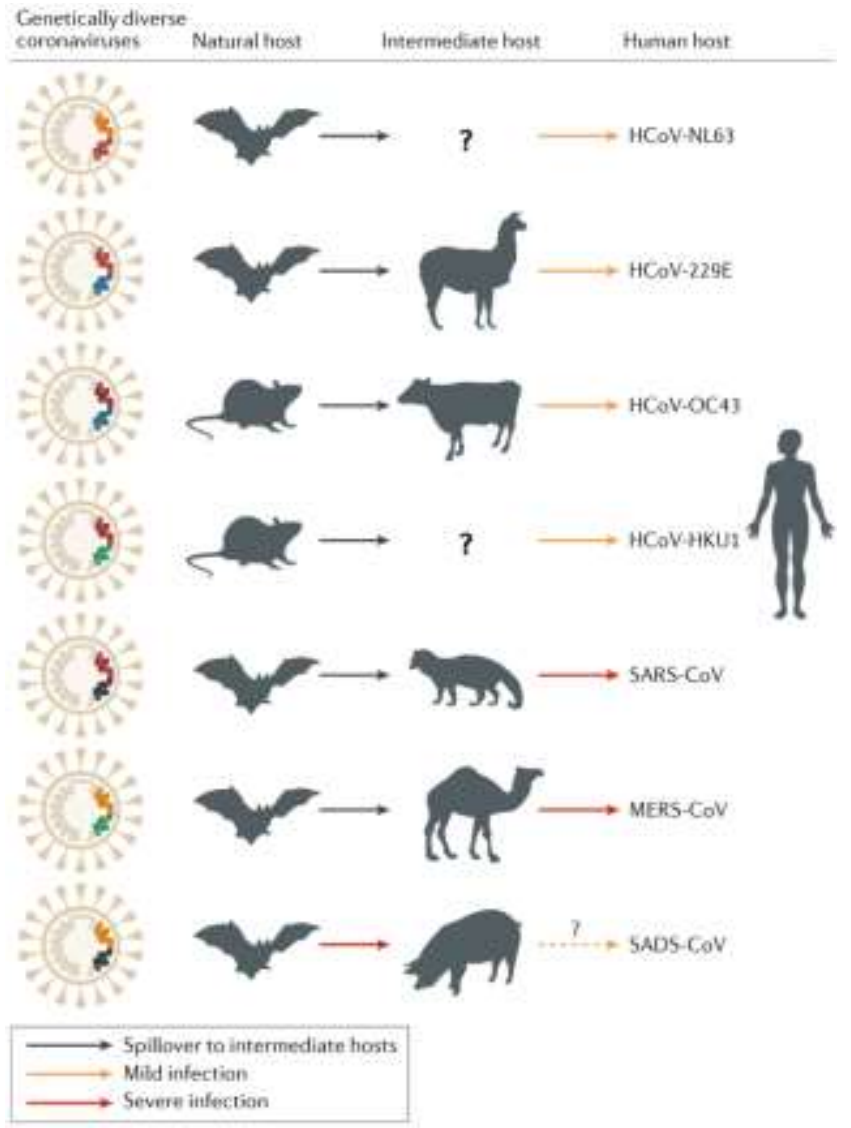

Fig. 2. Animal origins of human coronaviruses (Cui et al., 2019) 


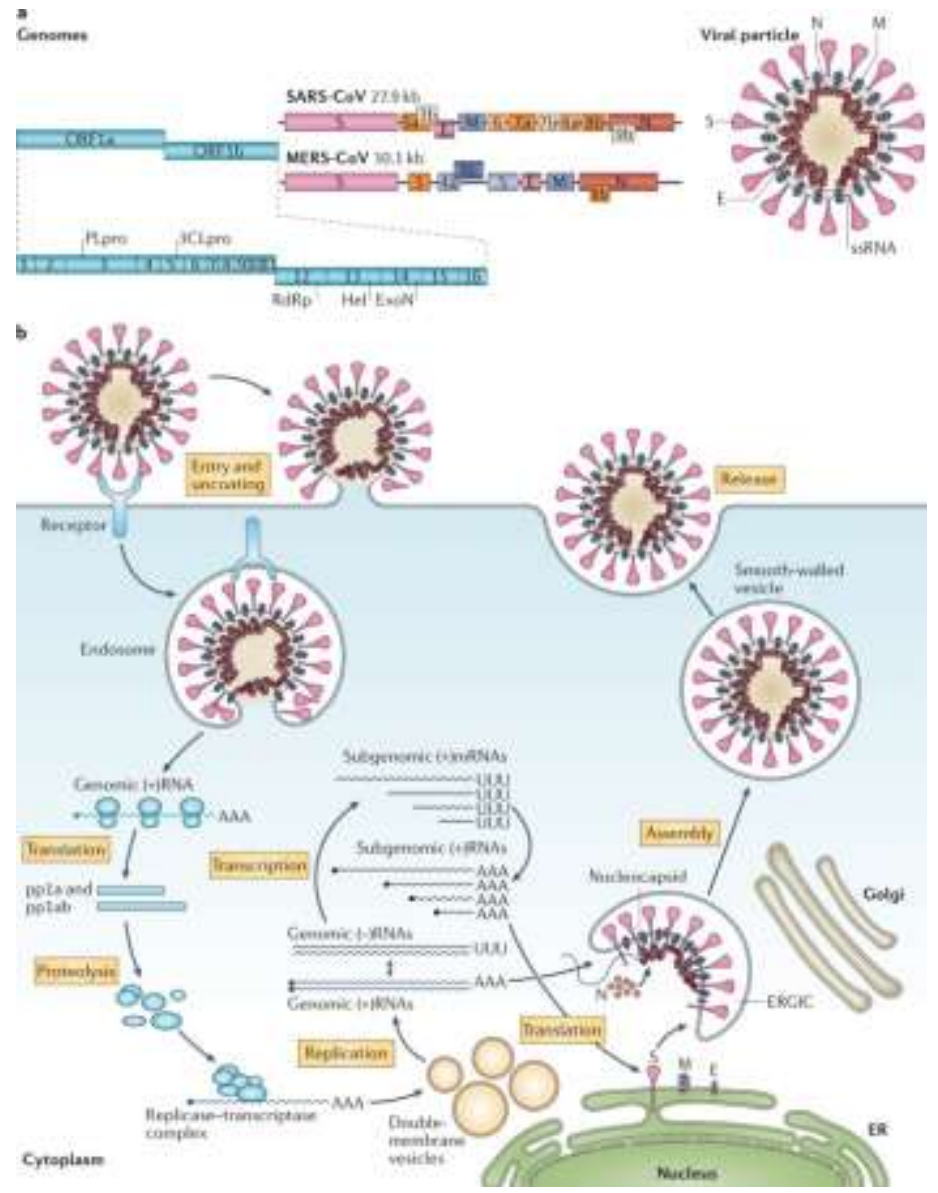

Fig. 3. SARS-CoV and MERS-CoV structure and replication (De Wit et al., 2016)

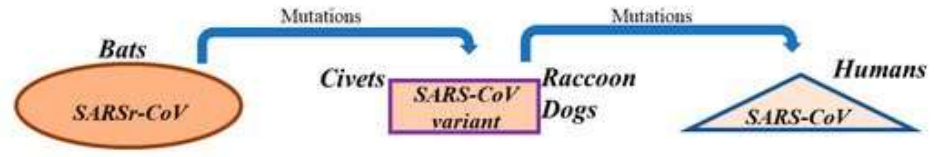

B.
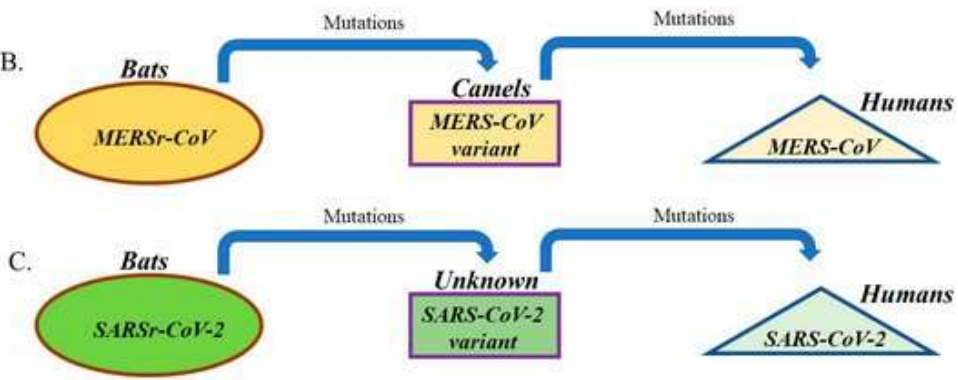

Fig. 4. Similarities and differences of SARS-CoV-1 (SARS-CoV), MERS-CoV, and SARS-CoV-2 (Covid-19) (Ashour et al., 2020) 